\title{
Factoren die een rol spelen bij het denken over rechtvaardige verdeling van vermogen en inkomen
}

Een surveyonderzoek onder de Nederlandse bevolking

Evert-Jan Rotshuizen, Helen Pluut en Willem van Boom

MEM 96 (1): 91-114

DOI: 10.5117/MEM2021.1.005.ROTS

\begin{abstract}
Factors That Influence How People Think About the Fairness of Distribution of Wealth and Income: A Survey Study Among Dutch Citizens

Ever since ancient Greece, people have philosophized and discussed about the fair distribution of resources. A body of empirical research on this topic has emerged in the second half of the 20st century. Oftentimes, respondents are presented with a distribution and asked whether they consider it just. In this paper, respondents are asked to allocate a sum of money across three families that represent distinct allocation principles - we study the principles of equality, need, subjective performance, and objective performance. We find that individuals heavily weigh the need principle in their allocation decisions. However, our research also shows that allocation behavior is on the one hand dependent on the situation and on the other hand associated with individual factors. Political preference and gender do not influence the allocation behaviors of individuals, but religion and age have the hypothesized effects.
\end{abstract}

Keywords: distributive justice, allocation principles, pluralism, allocation behavior, vignettes

\section{$1 \quad$ Inleiding}

Het Centraal Bureau voor de Statistiek (2019) bericht dat ruim een kwart van het totale private vermogen in ons land in handen is van een elite die 
slechts één procent van het totaal aantal huishoudens uitmaakt. En als we uitzoomen, wordt het beeld nog schever: de rijkste tien procent van de huishoudens bezit bijna twee derde van het totale vermogen, de bovenste $5^{\circ}$ procent bezit bijna 100 procent en de rest beschikt niet over een vermogen van enige omvang. Als we de cijfers in historisch perspectief plaatsen, valt bovendien een trendbreuk te bespeuren. Waar in de loop van de twintigste eeuw het vermogen juist evenrediger verdeeld raakte (Wilterdink, 2015), is het totale private vermogen van de bovenste één procent na de financiële crisis van 2008 weer snel toegenomen.

De vraag is of zo'n vermogensverdeling te rechtvaardigen is, zeker nu het aandeel van de bovenste één procent blijkt te stijgen. Laat het duidelijk zijn dat we hier niet een typisch Nederlands fenomeen aansnijden. Piketty (2014) noemt in zijn Kapitaal in de 21ste eeuw soortgelijke getallen voor de ons omringende landen. Piketty veronderstelt dat een oplopende ongelijkheid in de verdeling van vermogen allerminst is uitgesloten. De inkomensverdeling geeft een ietwat genuanceerder beeld; volgens Piketty (2019) verdient de bovenste één procent van de werkende bevolking in WestEuropese landen tien à 15 procent van het totaal besteedbaar inkomen in het desbetreffende land. Als men gevoelsmatig de inkomensverdeling anno nu niet rechtvaardig vindt, wat is dan wel een rechtvaardige verdeling? Die vraag is des te indringender als het om de vermogensverdeling gaat (Van Boom, 2019).

Het heeft lang geduurd voordat empirisch onderzoek werd gedaan naar een rechtvaardige verdeling. Het was de vraag of dat concept zich wel leende voor empirisch onderzoek. Maar Lamont en Favor (2017:19) stelden terecht: 'Distributive justice is not an area where we can say an idea is good in theory but not in practice. If it is not good in practice, then it is not good in theory either.' Wie zich bezighoudt met een rechtvaardige verdeling heeft het al snel over vermogen en inkomen. In dit artikel beogen we aansluiting te vinden bij de empirische realiteit en inzichten te verkrijgen in de rechtvaardigheidsbeginselen die individuen hanteren bij het verdelen van geld. Bestaand normatief en empirisch onderzoek maakt onderscheid tussen verschillende verdelingsbeginselen (Miller, 1999). Daarbij komen doorgaans de beginselen gelijkheid en behoefte voor, aangevuld met een derde beginsel dat wisselt (Cohn, White \& Sanders, 2000; Scott \& Bornstein, 20o9; Gatskova, 2013). Wij pleiten voor meer structuur in de veelheid van derde beginselen door die onder te brengen in twee categorieën, de $s u b$ jectieve prestatie en de objectieve prestatie. We hopen antwoord te vinden op twee onderzoeksvragen. Ten eerste, in welke mate verdelen individuen geld op grond van gelijkheid, behoefte, subjectieve prestatie en objectieve 
prestatie? Ten tweede, welke persoonskenmerken spelen een rol bij de oordeelsvorming? Wij dragen op deze manier bij aan theorie en empirisch onderzoek naar verdelingsgedrag en verdelende rechtvaardigheid. Hieronder bespreken we die literatuur alvorens we onze hypothesen formuleren en ingaan op de opzet van ons empirische studie.

\section{Theoretisch kader}

Bij een rechtvaardige verdeling van lusten en lasten, waaronder begrepen de verdeling van vermogen en inkomen, worden keuzes gemaakt en die keuzes zijn zelden of nooit waardevrij. Het denken over die keuzes is dus doordrenkt van ethische, filosofische en ideologische perspectieven. Uiteraard is er een rijke literatuur over rechtvaardige verdeling, te beginnen bij de Nicomachische ethiek van Aristoteles (385-322 voor Christus) in de polis, de Griekse stadstaat (1999 en 2005). Hij onderscheidt algemene en specifieke rechtvaardigheid. Bij de eerste komt het op gelijkheid aan: gelijkheid voor de wet, de toepassing van gelijkheid door de rechter en de toepassing van gelijkheid in contractuele verhoudingen. Het algemeen belang staat voorop. Bij de specifieke rechtvaardigheid gaat het om de verdeling van goederen. Aristoteles onderscheidt hierbij distributieve (of toedelende) en corrigerende rechtvaardigheid. De eerstgenoemde betreft gemeenschappelijke goederen, zoals aanzien en rijkdom, die in de stadstaat van zijn tijd werden verdeeld. Dat gebeurt naar verdienste en inspanning. Maar ook in private verhoudingen, bijvoorbeeld bij het aangaan van een contract, speelt die toedelende rechtvaardigheid. Volgens Aristoteles moet bij toedeling sprake zijn van een (evenredige) wederkerigheid tussen de betrokken partijen. De waardemaatstaf die hij hierbij hanteert, is de behoefte. Ten slotte, bij corrigerende rechtvaardigheid moet men denken aan onvrijwillige verhoudingen als gevolg van bijvoorbeeld diefstal. In zo'n geval moet de oorspronkelijke gelijkheid hersteld worden door compensatie voor het geleden nadeel.

De Nicomachische beginselen van gelijkheid, verdienste, inspanning en behoefte komen terug in nadien ontwikkelde filosofieën (Lamont \& Favor, 2017). Daarin speelt de vraag welke verdelingsbeginselen moeten worden toegepast om tot een rechtvaardige verdeling te komen. Piaget (1932) heeft als een van de eersten in de jaren dertig van de vorige eeuw in Zwitserland volgens een klinische methode onderzoek verricht bij kinderen over rechtvaardigheid en billijkheid. In de jaren zestig hebben in Noorwegen, op basis van de ideeën van Eckhoff (1966 en 1974) over rechtvaardigheid, Mathiesen (1965) en Naess (1969) empirisch onderzoek gedaan naar opvattingen over 
een rechtvaardige verdeling. Op grond van participerende observatie en grotendeels ongestructureerde interviews met zowel gedetineerden als bewakers, rapporteert Mathiesen (1965) dat gedetineerden regelmatig een beroep doen op rechtvaardigheid om zich in hun zwakke positie te kunnen handhaven. Hij onderscheidt daarbij verscheidene rechtvaardigheidsgronden. Naess (1969) vraagt zich af welke argumenten kinderen gebruiken bij de verdeling van door de onderwijzers te vergeven baantjes, straf, goedkeuring, cijfers, vragen en dergelijke. Op basis van semigestructureerde interviews met leerlingen van een basisschool en hun onderwijzers identificeert zij een aantal situaties waarbij een beroep op rechtvaardigheid wordt gedaan. Beide onderzoekers onderscheiden beginselen die wij relevant achten voor ons eigen onderzoek: het gelijkheidsbeginsel, het behoeftebeginsel, het subjectief prestatiebeginsel en het objectief prestatiebeginsel. Naast de al eerder uitgelegde beginselen van gelijkheid en behoefte, staat bij het subjectief prestatiebeginsel de persoonlijke inspanning van de persoon centraal. Dat kan geestelijke of fysieke inspanning zijn waarmee diegene zijn of haar brood verdient (bijvoorbeeld een boer, een kleine middenstander, een ICT'er), maar evengoed extra inspanning, zoals de bouwvakker, de tuinman of de boekhouder die in eigen vrije tijd bijverdienen of de vrijwilliger die's avonds of in het weekend extra uren maakt. Bij het objectief prestatiebeginsel gaat het om behaalde resultaten, de 'output' van de activiteiten van een bepaald persoon. Of die persoon daarvoor iets (bijzonders) heeft gedaan, is niet van belang. Zijn of haar maatschappelijke positie is doorslaggevend.

Mede onder invloed van het in 1972 verschenen boek A Theory of Justice van Rawls, komt in met name de Angelsaksische wereld in de jaren tachtig en negentig van de vorige eeuw sociaalpsychologisch, en later ook sociologisch, empirisch onderzoek over rechtvaardig verdelen op gang. Miller (1999) geeft daarvan een mooi overzicht en noemt een veelheid aan verdelingsbeginselen die daarbij gebruikt worden. Hij brengt die terug tot gelijkheid (equality), behoefte (need) en het verdienen van een beloning of een straf (desert). Als voorbeelden van het laatstgenoemde beginsel worden onder meer vaardigheid (skill), verantwoordelijkheid (responsibility), inspanning (effort), opleiding (education), beroep (occupation), billijkheid (equity), prestatie (achievement) en toekenning (ascription) genoemd. In feite fungeert 'desert' zo als een vergaarbak.

Gatskova (2013) pleit voor een multiprinciple justice theory waarin een pluralistisch begrip van rechtvaardigheid centraal staat dat gebaseerd is op verschillende verdelingsbeginselen. Deze theorie stelt dat wanneer individuen geconfronteerd worden met verdelingssituaties, zij verschillende verdelingsbeginselen of principes van rechtvaardigheid overwegen die zij 
in meer of mindere mate toepassen afhankelijk van de context en in lijn met bepaalde factoren, inclusief persoonskenmerken. Met ons onderzoek sluiten wij aan bij het werk van Miller (1999) over rechtvaardigheid en pluralisme en bij empirisch onderzoek dat geïnspireerd is op pluralistische theorieën van rechtvaardigheid (Scott \& Bornstein, 2009). Concreet stellen wij dus vier principes van een rechtvaardige verdeling centraal: het gelijkheidsbeginsel, het behoeftebeginsel, het subjectief prestatiebeginsel en het objectief prestatiebeginsel (zie Tabel 1 voor een overzicht). Met de twee soorten prestatiebeginselen menen wij dat naast gelijkheid en behoefte zo de mogelijkheid van een nauwkeurigere conceptualisering van verdelingsbeginselen ontstaat. Eerdergenoemde beginselen als effort, reponsibility, merit, desert (als beloning en als straf) en achievement zijn te scharen onder het subjectief prestatiebeginsel en beginselen als skill, pure chance, descent en ascription vallen onder het objectief prestatiebeginsel. Wij bouwen voort op een lijn van onderzoek dat kijkt naar de invloed van een scala aan factoren (cultureel, situationeel, demografisch, attitudes, persoonlijkheid) op de keuze voor verdelingsbeginselen (Arts \& Gelissen, 20o1; Bornstein, Gervais, Dietrich \& Escamilla, 2014; Cohn e.a., 2000). Concreet kijken we eerst naar de mate waarin de respondenten geld op grond van de genoemde vier beginselen verdelen. Daarna bestuderen wij de invloed van persoonskenmerken om het verdelingsgedrag van mensen in Nederland beter te begrijpen.

\section{Hypotheses}

We hebben ons de vraag gesteld welke verdelingsnormen in de Nederlandse maatschappij van het tweede decennium van deze eeuw van belang zijn. In de jaren vijftig tot zeventig van de vorige eeuw is de verzorgingsstaat opgebouwd, vooral gericht op de behoeftigen in onze samenleving. In de daaropvolgende decennia verschoof de aandacht naar het belang van het bedrijfsleven met als gevolg een sterke verrijking van bedrijven en hun bestuurders. In deze eeuw is de participatiemaatschappij opgekomen met veel eigen verantwoordelijkheid van de burger. Zo passeren achtereenvolgens het behoeftebeginsel, het objectief prestatiebeginsel (maatschappelijke positie) en het subjectief prestatiebeginsel (persoonlijke inspanning) de revue. Vooral bij rechten van de burger jegens de overheid (de rechtsstaat) komt het gelijkheidsbeginsel in beeld.

We zijn dus geïnteresseerd in hoe de Nederlandse bevolking van 18 jaar en ouder de hiervoor genoemde beginselen tegen elkaar afweegt. Dat komt in beeld bij de beschrijvende statistiek in de paragraaf Resultaten. 
Daarnaast willen we verklaren waarom de ene groep een bepaald beginsel wel onderschrijft en een andere groep niet. Daartoe hebben we een aantal hypotheses geformuleerd die betrekking hebben op de invloed van verschillende persoonskenmerken. We hebben ons bij de keuze voor persoonskenmerken laten leiden door wat ten tijde van het verzamelen van de data eind 2016 onderwerp van maatschappelijk debat was: de secularisatie (voor het eerst was de groep mensen die zich tot een religieuze groep rekende in de minderheid), de groei van populistische partijen, de man/ vrouw-discussie en de betaalbaarheid van pensioenen ofwel leeftijd: de ouderen versus de jongeren.

\subsection{De invloed van religie}

Christenen en moslims geloven in een rechtvaardige god. Dat geloof brengt barmhartigheid tegenover de medemens mee. In de Bijbel (Deuteronomium 10:18 en Matteüs 25:40) en de Koran (Soera 2, 177) lezen we dit. Gelovigen worden aangespoord om behoeftigen materieel te helpen. Dit gegeven vinden we in het protestantisme terug in onder meer de diaconie en zending, in het rooms-katholicisme in bijvoorbeeld de zeven werken van barmhartigheid en in de islam in onder andere de zakaat, een verplichte armenondersteuning. Dit zou kunnen betekenen dat de respondenten die zich tot een van de genoemde religies rekenen, de behoeftige families een warmer hart toedragen dan de niet-gelovigen. Wij verwachten dan ook dat de daadwerkelijke zorg voor de naaste, zoals in de Bijbel en Koran en in de daarvan afgeleide moraalleer wordt voorgeschreven, in onze geseculariseerde samenleving bij de gelovigen meer doorleefd is dan bij de niet-gelovigen. Op basis hiervan luidt onze hypothese:

Hypothese 1: Wie gelooft (protestants, rooms-katholiek, islamitisch) zal meer voor het behoeftebeginsel kiezen dan iemand die niet gelovig is.

\subsection{De werking van het populisme}

Piketty (2019) heeft beschreven hoe de sociaaldemocratische partijen in West-Europa hun roeping, namelijk die van hoeder van het gewone volk, langzaam verloren en zich vanaf de jaren tachtig van de vorige eeuw ontwikkelden tot bestuurderspartijen. Hun parlementariërs zijn hoog opgeleid en hebben weinig voeling meer met de arbeidersklasse. Te Velde (2010), Reybrouck (2011) en Lucardie en Voerman (2012) verklaren de opkomst van populistische partijen in Nederland - met name de Socialistische Partij (SP) en de Partij voor de Vrijheid (PVV) - grotendeels door de teloorgang 
van met name de Partij van de Arbeid. Die populistische partijen benadrukken de kloof tussen het volk en de elite die alleen het eigen belang najaagt. Zij komen juist op voor de behoeften van dat volk, met name van de arbeidersklasse en kleine middenstand.

Zo heeft het populisme in de loop van de afgelopen twintig à dertig jaar steeds meer invloed op de Nederlandse politiek gekregen. De SP verkreeg haar eerste zetels in de Tweede Kamer in 1994 en de PVV in 2006. ${ }^{1}$ Afgaande op hun respectievelijke partijprogramma kenmerken de genoemde populistische partijen zich door hun zorg voor de kleine man of vrouw die onder meer gebaat is bij lage kosten voor de zorg en lage belasting op de eerste levensbehoeften. De PVV maakt zich onder meer sterk voor een lagere BTW, voor lastenverlaging voor de burger en voor behoud van de 'Agema-gelden' (12.000 extra zorgmedewerkers). Ze wil geen verhoging van de eigen bijdrage in de zorgverzekering (PVV, 2012). De SP wil geen aantasting van de koopkracht door verhoging van de BTW, het eigen risico in de zorg moet omlaag, zorgpremies moeten inkomensafhankelijk worden en er moeten in de zorg meer handen aan het bed komen (SP, 2013-2017).

Tegenover de populistische partijen staat als grootste politieke partij de Volkspartij voor Vrijheid en Democratie (VVD), die met name opkomt voor de belangen van de kapitaalkrachtigen (hoge inkomens, grote vermogens, bedrijfsleven). De verschillen tussen de maatschappijvisie van de populistische partijen en die van de VVD (2012-2019) zijn groot. Gelet op de inhoud van de partijprogramma's proberen de populistische partijen te voorzien in de behoeften van de kleine man of vrouw, terwijl de VVD de belangen van de 'hardwerkende ondernemer' dient. Dit brengt ons tot de volgende hypotheses:

Hypothese 2a: VVD-stemmers zullen meer voor het objectief prestatiebeginsel en/ of het subjectief prestatiebeginsel kiezen dan stemmers op de overige partijen. Hypothese 2b: SP-stemmers zullen meer voor het behoeftebeginsel kiezen dan stemmers op de overige partijen.

Hypothese 2c: PVV-stemmers zullen meer voor het behoeftebeginsel kiezen dan stemmers op de overige partijen.

\subsection{De voorkeur van vrouwen versus die van mannen}

Er is veel theoretisch onderzoek beschikbaar over de vraag of geslacht een beslissende factor ten gunste van het behoeftebeginsel zou kunnen zijn. Zo schrijft Gilligan (1982) dat vrouwen gevoelig zijn voor de noden van anderen en dat zij anderen helpen alleen al omdat dat van hen verwacht 
wordt. Dit is in lijn met een invloedrijke theorie uit de sociale psychologie, namelijk de sociale-roltheorie van Eagly (1987). Die concludeert dat mannen en vrouwen verschillende rollen in de maatschappij aannemen en daarom andere eigenschappen ontwikkelen; vrouwen zijn doorgaans behulpzaam en coöperatief (de zogenaamde communal eigenschappen), terwijl mannen assertief en competitief zijn (de zogenaamde agentic eigenschappen). Howell en Day (2000: 859) menen in lijn hiermee dat de stelling ' $[t]$ hat female morality tends to be more cooperative, caring and nurturing', juist is. Empirisch onderzoek geeft echter een verdeeld beeld. Waar sommige onderzoeken op grond van data inderdaad concluderen dat vrouwen gevoeliger zijn voor behoeftigheid (Arts e.a., 20o1; Kleuger \& Miyano, 1995), bestrijden andere empirische studies de opvatting dat vrouwen zorgzamer zijn dan mannen (Debusscher \& Elchardus, 2002; Linkey \& Alexander, 1998; Van Oorschot, 20oo). Dit alles onderschrijft het belang van verder empirisch onderzoek. Wij hebben voor onze hypothese aansluiting gezocht bij de theorie en stellen ons op het standpunt dat vrouwen eerder dan mannen gedrag zullen vertonen dat gericht is op het welzijn van anderen.

Hypothese 3: Vrouwen zullen meer dan mannen kiezen voor het behoeftebeginsel.

\subsection{De factor leeftijd}

Volgens Durkheim (1968) is de samenleving een sociaal systeem dat zichzelf genereert, zichzelf in stand houdt en zichzelf ontwikkelt. Eigen daaraan is dat bij oudere mensen een meer bezonken oordeel over het voortbestaan van die samenleving als geheel mag worden verwacht. Arts e.a. (2001) hebben uit internationale data afgeleid dat met het stijgen van de jaren de voorkeur voor het beginsel van gelijkheid toeneemt en die voor het behoeftebeginsel afneemt, terwijl elders is gevonden dat ouderen duidelijk meer solidair zijn met behoeftigen dan jongeren (Roosma, 2009). Als we ons beperken tot data van de bevolking in Nederland, geeft het rapport Verschil in Nederland - Sociaal en cultureel rapport 2014 onder redactie van Vrooman, Boelhouwer en Gijsberts de nodige informatie. Hierin valt te lezen dat ouderen meer dan jongeren kiezen voor inkomensnivellering (Dekker \& Den Ridder, 2014) en bovendien meer bereid zijn om inkomen in te leveren ten gunste van jongeren dan andersom (Vermeij, Sonck \& Van den Broek, 2014). Ouderen lijken dus meer oog voor de noden van jongeren te hebben en voelen zich in ieder geval niet behoeftig. Vertaald naar ons onderzoek denken we dat ouderen meer dan jongeren voor het behoeftebeginsel kiezen. Jongeren, zo verwachten we, moeten hun plaats in de samenleving nog 
vinden en zullen een voorkeur hebben voor het objectief prestatiebeginsel en, gelet op de nadruk op prestatie in onze samenleving, nog meer voor het subjectief prestatiebeginsel.

Hypothese 4: Ouderen zullen meer dan jongeren voor het behoeftebeginsel kiezen en jongeren meer dan ouderen voor het objectief prestatiebeginsel en/of het subjectief prestatiebeginsel.

\section{$4 \quad$ Data en methoden}

We willen onderzoeken enerzijds in hoeverre mensen bij concrete verdelingsvragen oordelen op grond van behoefte, gelijkheid, subjectieve prestatie en objectieve prestatie en anderzijds in welke mate persoonskenmerken

Tabel 1 Operationalisering van de beginselen

\begin{tabular}{|c|c|c|}
\hline Beginsel & Criteria & Operationalisering $^{\text {a }}$ \\
\hline Gelijkheidsbeginsel & Gelijkheid (equality) & Alle casus: ieder evenveel \\
\hline Behoeftebeginsel & Behoefte (need) & $\begin{array}{l}\text { Casus 1: zorg voor vier kinderen, man werkt } \\
\text { veel, beperkt inzetbaar thuis } \\
\text { Casus 2: weduwe met een klein pensioen en } \\
\text { de zorg voor drie kinderen } \\
\text { Casus 4: alleenstaande vrouw met beperkt } \\
\text { inkomen en een handicap } \\
\text { Casus 5: laag salaris, drie kinderen, lange } \\
\text { reistijd en zo geen tijd voor extra's }\end{array}$ \\
\hline $\begin{array}{l}\text { Subjectief prestatie- } \\
\text { beginsel }\end{array}$ & $\begin{array}{l}\text { Persoonlijke fysieke of geestelijke } \\
\text { inspanning, eigen aan het beroep of als } \\
\text { extra naast de vaste werkzaamheden } \\
\text { (effort, merit, desert, achievement) }\end{array}$ & $\begin{array}{l}\text { Casus 1: lange werktijden, fysieke inspan- } \\
\text { ning, vrouw helpt mee in zaak } \\
\text { Casus 2: drukke buurtwinkel, lange } \\
\text { werktijden } \\
\text { Casus 4: gebrek aan opleiding, maar door } \\
\text { hard te werken en te leren zich opgewerkt } \\
\text { Casus 5: laag salaris maar door's avonds bij } \\
\text { te klussen behoorlijke bijverdiensten }\end{array}$ \\
\hline $\begin{array}{l}\text { Objectief prestatiebe- } \\
\text { ginsel }\end{array}$ & $\begin{array}{l}\text { Centraal staat de plaats die de persoon } \\
\text { in kwestie in de samenleving inneemt. } \\
\text { Of die persoon daarvoor wel of niet } \\
\text { iets bijzonders heeft gedaan, is niet } \\
\text { van belang. (skill, descent, pure chance, } \\
\text { ascription) }\end{array}$ & $\begin{array}{l}\text { Casus 1: de familie is eigenaar van drie } \\
\text { bloemenzaken } \\
\text { Casus 2: directeurschap, een ruim huis } \\
\text { Casus 4: hoge positie in een bedrijf } \\
\text { Casus 5: onderdirecteur van een fabriek }\end{array}$ \\
\hline
\end{tabular}


een rol spelen bij hun verdelingsgedrag. Daartoe hebben we een vragenlijst ontwikkeld, die voorafgaande aan de afname in diverse proefinterviews getest is. Vervolgens hebben we I\&O Research in Amsterdam, een gecertificeerd onderzoeksbureau met een representatief respondentenpanel, opdracht gegeven om de vragenlijst af te nemen. ${ }^{2}$ Dat is gebeurd in het najaar van 2016. Een totaal van 2332 personen heeft digitaal de vragenlijst ingevuld. De samenstelling van de groep respondenten is zodanig dat ruimschoots aan de zogeheten Gouden Standaard voor de representativiteit van de steekproef voor de Nederlandse bevolking van 18 jaar of ouder is voldaan.

De vier afhankelijke variabelen betreffen de verdelingsbeginselen. In een viertal casus $^{3}$ zijn die geoperationaliseerd, zoals weergegeven in tabel 1. Aan de respondenten worden een viertal rondes verdelingsvragen (casus) voorgelegd (zie de appendix voor een overzicht van de casus). In iedere casus worden steeds drie families beschreven. Een voorbeeld uit die vragenlijst (casus 5) leest als volgt:

Meneer Van Zanen is onderdirecteur van een fabriek. Hij woont in een van de buitenwijken van de stad. Hij is getrouwd en heeft vier jonge kinderen.

Meneer Van Pelt is metaalarbeider. De fabriek waar hij werkt is over de kop gegaan en hij werkt nu in een fabriek in een andere stad. De verbinding met het openbaar vervoer tussen de beide steden is slecht. Als gevolg daarvan is hij veel tijd kwijt met reizen. Hij is getrouwd en heeft drie jonge kinderen.

Meneer Kruiters is ook metaalarbeider en werkt op dezelfde fabriek als meneer Van Pelt. Hij woont in de stad waar de fabriek staat. Hij gaat meestal op de fiets naar zijn werk. 's Avonds knapt hij regelmatig dingen bij andere mensen op. Daarvoor heeft hij een auto nodig. Hij verdient zo een aardig centje bij. Hij is getrouwd en heeft twee jonge kinderen.

In dit voorbeeld staat de familie Van Zanen voor het objectief prestatiebeginsel. Hij heeft een maatschappelijke positie met aanzien en een overeenkomstig inkomen. Dat ligt wezenlijk anders voor de familie Van Pelt. Als metaalarbeider verdient hij ergens tussen het minimumloon en modaal. Bovendien is hij door de lange dagelijkse reistijd niet in staat om nog wat bij te verdienen. Zijn familie vertegenwoordigt het behoeftebeginsel. De familie Kruiters heeft het ruimer vanwege de bijverdiensten in de avonduren. Vanwege zijn extra inspanning verbeeldt hij het subjectief prestatiebeginsel. De respondent krijgt de beschikking over $€ 1000$ met de vraag dat bedrag over de drie families te verdelen op een manier die hij/zij rechtvaardig 
vindt. Ook wordt de vraag gesteld of de respondent het geld anders zou verdelen als het niet om $€ 1000$ maar $€ 100$ zou gaan. Gelet op de lengte van het artikel zien we grotendeels af van bespreking van die variant. De respondent mag vanzelfsprekend de drie families evenveel toekennen. Een evenredige verdeling over alle families - bij $€ 1000$ dus ieder $€ 333$ - staat voor het gelijkheidsbeginsel. Maar evengoed kan de respondent het bedrag van $€ 1000$ ongelijk over de families verdelen. De respondent kan niet verder met invullen van de vragenlijst als deze een verdeling heeft gemaakt die niet op € 1000 uitkomt. Zo ontstaat een genuanceerd beeld van de rechtvaardige verdeling die de respondent voor ogen staat en hoe zwaar de genoemde beginselen wegen. Daarnaast zijn wij op zoek naar het beginsel dat in een bepaalde situatie leidend is voor het verdelen van geld. De vier beginselen zijn daarom gedichotomiseerd. Zo wordt bij een evenredige verdeling het gelijkheidsbeginsel gecodeerd als 1 (versus o) en komen de andere beginselen op o te staan. Deze binaire codering geeft de relatieve zwaarte van het betrokken beginsel aan en sluit aan bij de formulering van onze hypothesen. Een kanttekening is hier echter op zijn plaats. Bedacht moet worden dat als bijvoorbeeld het behoeftebeginsel op de eerste plaats staat, dat kan betekenen dat het volledige bedrag van $€ 1000$ volgens dat beginsel wordt toegedeeld, maar dat dat evenzeer geldt voor een verdeling met $€ 400$ volgens het behoeftebeginsel, $€ 300$ volgens het subjectief prestatiebeginsel en $€ 300$ volgens het objectief prestatiebeginsel.

De onafhankelijke variabelen betreffen de persoonskenmerken en zijn als volgt geoperationaliseerd. Religie is gemeten met de vraag 'Zou u zichzelf een gelovig mens noemen?', die respondenten met 'ja' of 'nee' konden beantwoorden. De referentiecategorie is hier 'niet-gelovig'. Geslacht is ook gemeten als een dichotome variabele en heeft als referentiecategorie vrouw. Politieke voorkeur is gemeten met de vraag 'Als er nu verkiezingen voor de Tweede Kamer zouden worden gehouden, op welke partij zou u stemmen?' Tot de antwoordcategorieën behoorden de verschillende politieke partijen (eventueel in te vullen bij 'anders, namelijk') alsook 'ik ga niet stemmen' en 'ik wil dat niet zeggen'. De politieke partijen waar onze hypotheses op betrekking hebben, zijn als dichotome variabelen opgenomen, waarbij stemmers van die partij (bijvoorbeeld VVD-stemmers) worden vergeleken met alle anderen (in dit geval niet-VVD-stemmers). Ten behoeve van aanvullende analyses hebben we ook een multicategoriale variabele voor politieke voorkeur gebruikt, waarbij de categorieën als dichotome variabelen (SP, PVV) afgezet worden tegen VVD als referentiecategorie. Leeftijd is gemeten middels een numerieke open vraag. In tabel 2 geven we enkele beschrijvende statistieken die de steekproef beschrijven. 
Tabel 2 Beschrijvende statistieken van de steekproef $(\mathrm{N}=2332)$

\begin{tabular}{lc}
\hline Onafhankelijke variabele & Percentages \\
\hline Religie & Gelovig Niet-gelovig \\
& $35 \quad 65$ \\
Geslacht & Man Vrouw \\
& $61,438,6$ \\
VVD-stemmers & $16,0(n=372)$ \\
SP-stemmers & $8,6(n=200)$ \\
PVV-stemmers & $6,2(n=144)$ \\
Leeftijda & $57,6(15,0)$ \\
\hline a Voor de continue variabele leeftijd is het gemiddelde en tussen haakjes de standaarddeviatie gerapporteerd.
\end{tabular}

In de resultatensectie worden eerst cirkel- en staafdiagrammen met beschrijvende statistiek gepresenteerd. Het betreft hier geaggregeerde statistieken van vier casus. De grafieken laten zien hoe respondenten gemiddeld genomen het geld verdelen over de drie families en hoe de vier beginselen zich tot elkaar verhouden. Na de beschrijvende analyse van de gevonden resultaten gaan we over to thet toetsen van de hypotheses. We schatten logistische regressiemodellen en kijken naar het leidend beginsel zoals hierboven behandeld. Omdat elke afhankelijke variabele twee categorieën heeft, betreft het een binaire logistische regressieanalyse. De resultaten hiervan zijn te vinden in tabel 3. Bij deze analyse wordt een voorspellend persoonskenmerk gerelateerd aan de relatieve kans op een bepaalde uitkomst, dat wil zeggen de kans dat een beginsel als leidend wordt gehanteerd ten opzichte van de kans dat dit beginsel niet als leidend wordt gehanteerd. Wanneer we bijvoorbeeld geslacht als voorspellend persoonskenmerk relateren aan het behoeftebeginsel, vergelijken we de zogenaamde odds van vrouwen met die van mannen. Die verhouding in kansen wordt uitgedrukt in een getal tussen o en oneindig, de zogeheten oddsratio. Gezien de referentiecategorie van de variabele geslacht betekent een getal tussen o en 1 hier dat vrouwen meer dan mannen voor het behoeftebeginsel als leidend kiezen. Bij een getal groter dan 1 merken mannen meer dan vrouwen het behoeftebeginsel als leidend beginsel aan. Voor aanvullende inzichten hebben we daarnaast een multinomiale logistische regressie toegepast. De afhankelijke variabele, het beginsel, heeft hier meerdere (wederzijds uitsluitende) categorieën. Bij deze analyse is het gelijkheidsbeginsel altijd de referentiecategorie, zodat als het ware het afwijken van een gelijke verdeling wordt gemeten. De resultaten hiervan zijn te vinden in tabel 4 . We hanteren een betrouwbaarheidsinterval van 95 procent (dus $\alpha \leq 0,05$ ).

We beschikken over veel materiaal voor de toetsing van de hypotheses, omdat we respondenten verschillende casus hebben voorgelegd. Dat heeft 
tot gevolg dat de herhaalde metingen als het ware ingebed of 'genest' zijn in personen. Met dit soort data is het toepassen van een multiniveau-analyse op zijn plaats (Tabata, Thomas \& Heck, 2012). Deze vorm van analyse neemt in acht dat de antwoorden van een en dezelfde respondent niet geheel onafhankelijke observaties zijn. Het idee is namelijk dat respondenten een bepaalde rechtvaardige verdeling voor ogen hebben die in alle casus tot uiting wordt gebracht. Er wordt op twee niveaus gemeten: dat van de persoon (met zijn/haar eigen kenmerken) en dat van de casus (met specifieke eigenschappen). Het antwoord van een respondent is dus afhankelijk van zowel de eigen persoonskenmerken als de specifieke eigenschappen van de gepresenteerde casus. Een kanttekening bij de beschrijvende resultaten (die laten zien hoe respondenten over de volle breedte geld verdelen) is dat respondenten niet altijd consistent zijn in hun verdelingen in de verschillende casus. Sterker nog, de variatie in de bedragen voor de families is voor een substantieel deel toe te schrijven aan verschillen tussen de casussen. Er is dus een relatief grote spreiding van de getallen rond de gemiddelden in de grafieken. Daarom is het voor de lezer belangrijk om in het achterhoofd te houden dat er contextualiteit van oordelen is: er zijn weliswaar patronen in de toekenning van bedragen te ontdekken in de geaggregeerde gegevens (ook op basis van persoonskenmerken), maar de bijzonderheden van de families in de casus zelf spelen een rol van betekenis bij de oordeelsvorming over rechtvaardige verdeling. Om een voorbeeld te geven: van alle variatie in de bedragen toegekend aan behoeftige families betrof 71 procent de verschillen tussen casussen en 29 procent de verschillen tussen respondenten. Van belang is echter dat de verschillen tussen de respondenten in alle gevallen substantieel waren en er derhalve sprake is van clustering. Wij zullen daarom de binaire logistische regressie toepassen binnen een model van de multiniveau-analyse (Tabata e.a., 2012). Het betreft hier een holistische toets van de gehypothetiseerde verbanden die één gebundelde schatting van de sterkte van een verband oplevert. Op die manier zijn we in staat een conclusie te trekken of er voldoende steun is over de breedte van de verdelingen om tot een bevestiging van de hypotheses te komen.

\section{$5 \quad$ Resultaten}

\subsection{Beschrijvende statistieken}

Figuur 1 laat zien hoe respondenten de $€ 1000$ verdelen in het hierboven gegeven voorbeeld. De verdeling van het totale beschikbare bedrag (in vier casus) leert dat de behoeftige families ruim de helft van het geld krijgen toebedeeld. Toch wordt in 35 procent van de gevallen gelijk verdeeld. Dat 


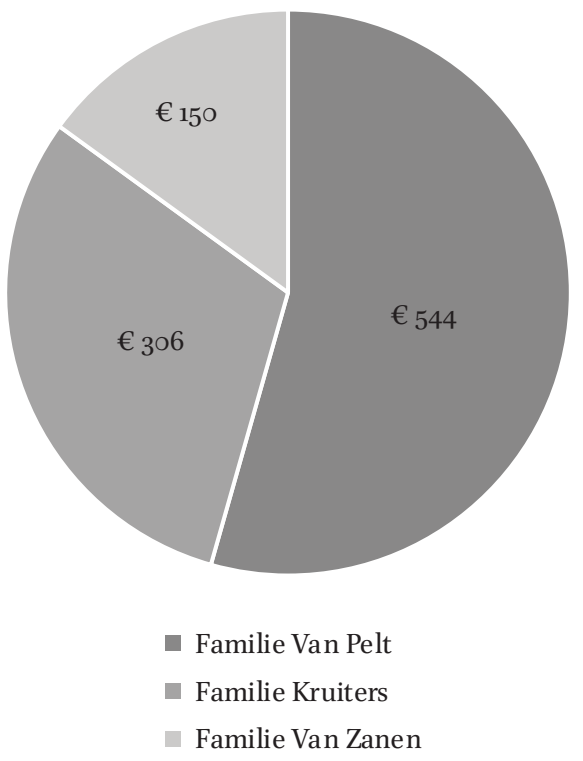

Figuur 1 Voorbeeld van verdeling van $€ 1000$

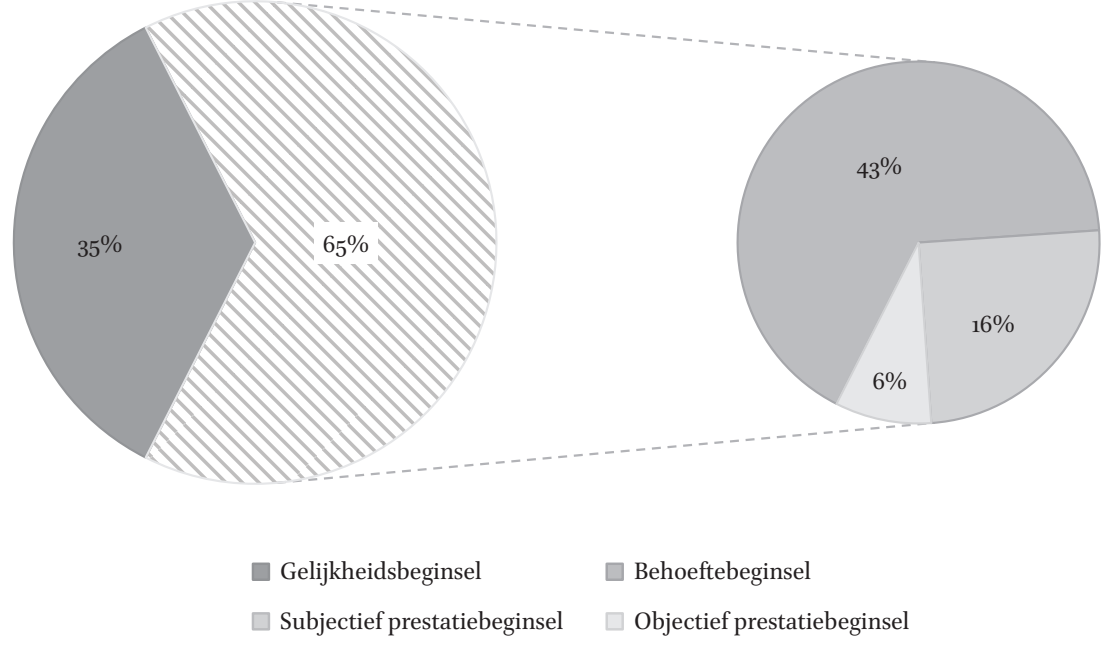

Figuur 2 Beginselen in percentages

is te zien in figuur 2, waar wordt overgestapt van de families naar de onderliggende beginselen om in te kaart te brengen hoe de vier beginselen zich precies tot elkaar verhouden. De opgesplitste cirkeldiagrammen tonen dat als er geen sprake is van (grote) behoeftigheid, er veel ruimte is voor verdeling volgens het gelijkheidsbeginsel. 


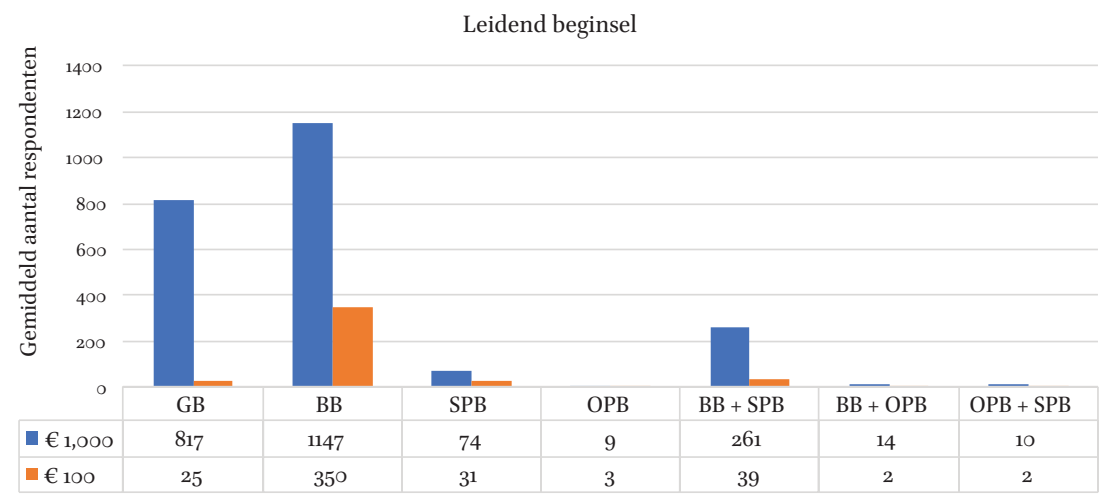

Figuur 3 Dominantie van (combinatie van) beginselen

Noot: We werken ter wille van de overzichtelijkheid van de figuur met afkortingen: $G B$ = gelijkheidsbeginsel, $B B=$ behoeftebeginsel, $S P B=$ subjectief prestatiebeginsel, $O P B=$ objectief prestatiebeginsel, $B B+S P B=$ evenveel behoeftebeginsel als subjectief prestatiebeginsel, $B B+O P B=$ evenveel behoeftebeginsel als objectief prestatiebeginsel, SPB $+O P B=$ evenveel subjectief prestatiebeginsel als objectief prestatiebeginsel. $N=2332$ bij de verdeling van $€ 1000$ en $N=450$ bij de verdeling van $€ 100$.

Wanneer we kijken naar het aantal respondenten dat een bepaald beginsel of een combinatie daarvan leidend vindt, levert dat de staafdiagrammen in figuur 3 op. We rapporteren hier voor de volledigheid zowel de resultaten voor standaardverdelingen als voor de varianten met $€$ 100. De statistieken voor $€ 100$ betreffen alleen de gevallen waar respondenten besloten anders te verdelen bij een kleiner bedrag. In 78,9 tot 82,8 procent van de gevallen bleven mensen bij hun eerdere verdeling. Over de verschillende verdelingen krijgt gemiddeld genomen het gelijkheidsbeginsel een behoorlijke aanhang, maar het behoeftebeginsel is in de meeste gevallen het leidend beginsel. Die dominantie van het behoeftebeginsel is nog sterker wanneer respondenten minder geld (namelijk $€$ 10o) te verdelen hebben. Naarmate er minder te verdelen valt, vinden respondenten behoefte belangrijker als verdelingsbeginsel. Opvallend is ook het relatief grote aantal respondenten dat voor de combinatie van het behoeftebeginsel en het subjectief prestatiebeginsel kiest.

\subsection{Binaire logistische regressie}

Figuur 3 toont dat weinig respondenten de prestatiebeginselen als leidend hanteren. Wij zijn daarom genoodzaakt in de verdere analyses het subjectief en objectief prestatiebeginsel samen te voegen. Tabel 3 toont de resultaten van de binaire logistische regressieanalyses, waarbij de verdelingsbeginselen als afhankelijke variabelen centraal staan. De verschillende persoonskenmerken 
worden tezamen gebruikt om het onderschrijven van een verdelingsbeginsel te voorspellen, dus er is hier sprake van meervoudige regressies. De eerste hypothese betreft de factor religie en stelt dat gelovigen meer voor het behoeftebeginsel zullen kiezen dan niet-gelovigen. De toets levert een significant en positief verband op tussen religie en het behoeftebeginsel. De oddsratio $\left(\frac{\text { gelovig }}{\text { niet gelovig }}\right)$ geeft weer dat de kans dat een gelovige geld verdeelt volgens het behoeftebeginsel, 1,14 keer zo groot is als dat een ongelovige dat doet. Tabel 4 laat zien dat wanneer we middels een multinomiale logistische regressie de keuze voor het behoeftebeginsel afzetten tegen die voor het gelijkheidsbeginsel, gelovigen meer dan niet-gelovigen het behoeftebeginsel verkiezen boven het gelijkheidsbeginsel $(B=0,16, p=0,007)$. Dit is ook terug te zien in tabel 3 in het model voor het gelijkheidsbeginsel, dat een negatieve coëfficiënt oplevert voor religie. Hypothese 1 is bevestigd.

Tabel 3 Binaire logistische regressieanalyses met leidend beginsel als uitkomst

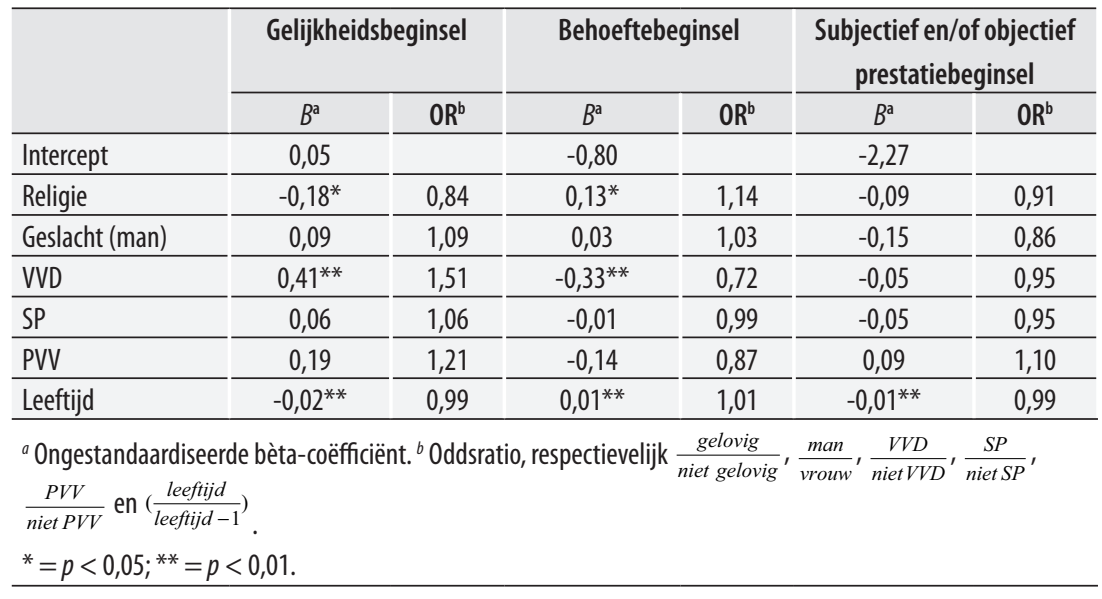

De tweede hypothese over politieke voorkeur bestaat uit drie onderdelen. Wat betreft de VVD-stemmers vinden we geen bewijs voor de verwachting dat zij de prestatiebeginselen als leidend hanteren. In plaats daarvan is het gelijkheidsbeginsel leidend onder VVD-stemmers. De conclusie is dat dit deel van de hypothese moet worden verworpen. Wat betreft SP-stemmers, het tweede onderdeel van de hypothese, zien we dat er gemiddeld genomen geen sprake is van een significante voorkeur van SP-stemmers ten opzichte van niet-SP-stemmers voor het behoeftebeginsel. Als we de voorkeur van SP-stemmers voor het behoeftebeginsel echter afzetten tegen de voorkeur van VVD-stemmers voor dat beginsel, blijkt er sprake van een significant verschil ten gunste van de SP-stemmers $(B=0,32, p=0,010)$. Toch is de 
Tabel 4 Multinomiale logistische regressieanalyses met gelijkheidsbeginsel als referentiecategorie

\begin{tabular}{|c|c|c|c|c|c|c|c|c|}
\hline & \multicolumn{2}{|c|}{$\begin{array}{c}\text { Behoeftebegin- } \\
\text { sel }^{\mathrm{a}}\end{array}$} & \multicolumn{2}{|c|}{$\begin{array}{c}\text { Behoeftebeginsel } \\
\text { en subjectief pres- } \\
\text { tatiebeginsel }^{\mathrm{a}} \\
\end{array}$} & \multicolumn{2}{|c|}{$\begin{array}{c}\text { Behoeftebeginsel } \\
\text { en objectief pres- } \\
\text { tatiebeginsel }{ }^{\mathrm{a}} \\
\end{array}$} & \multicolumn{2}{|c|}{$\begin{array}{c}\text { Subjectief en/of } \\
\text { objectief prestatiebe- } \\
\text { ginsel }^{\mathrm{a}}\end{array}$} \\
\hline & $B^{b}$ & $O R^{c}$ & $B^{b}$ & $\mathrm{OR}^{\mathrm{c}}$ & $B^{b}$ & $\mathrm{OR}^{\mathrm{c}}$ & $B^{b}$ & $\mathrm{OR}^{\mathrm{c}}$ \\
\hline Intercept & $-0,46$ & & $-1,80$ & & $-3,55$ & & $-1,57$ & \\
\hline Religie & $0,16^{* *}$ & 1,17 & 0,17 & 1,18 & 0,23 & 1,26 & $-0,07$ & 0,93 \\
\hline Geslacht (man) & $-0,04$ & 0,96 & $-0,19^{*}$ & 0,83 & 0,11 & 1,12 & $-0,31^{*}$ & 0,74 \\
\hline VVD & $-0,38^{* *}$ & 0,69 & $-0,21$ & 0,81 & $-0,13$ & 0,88 & $-0,30$ & 0,75 \\
\hline SP & $-0,03$ & 0,97 & $-0,04$ & 0,96 & $-0,20$ & 0,82 & $-0,12$ & 0,89 \\
\hline PVV & $-0,17$ & 0,84 & $-0,22$ & 0,80 & $-0,29$ & 0,75 & 0,05 & 1,06 \\
\hline Leeftijd & $0,02^{* *}$ & 1,02 & $0,01^{* *}$ & 1,01 & $-0,01$ & 0,99 & $-0,01$ & 0,99 \\
\hline \multicolumn{9}{|c|}{$\begin{array}{l}\text { a De kans op een beginsel of combinatie van beginselen als leide } \\
\text { gelijkheidsbeginsel als leidend. b Ongestandaardiseerde bèta-co } \\
\frac{\text { gelovig }}{\text { niet gelovig }}, \frac{\text { man }}{\text { vrouw }}, \frac{V V D}{\text { niet } V V D}, \frac{S P}{\text { niet } S P}, \frac{P V V}{\text { niet } P V V} \text { en }\left(\frac{\text { leeftijd }}{\text { leeftijd }-1}\right) \text {. } \\
{ }^{*}=p<0,05 ;{ }^{*}=p<0,01 \text {. }\end{array}$} \\
\hline
\end{tabular}

conclusie dat dit deel van de hypothese moet worden verworpen. Wat betreft het derde onderdeel blijken PVV-stemmers het behoeftebeginsel niet als leidend beginsel te hanteren in de verschillende casus. We hebben geen verschil gevonden tussen VVD- en PVV-stemmers in hun voorkeur voor een van de beginselen. De conclusie is dat ook het derde deel van hypothese 2 moet worden verworpen.

De derde hypothese luidt dat vrouwen meer dan mannen kiezen voor het behoeftebeginsel. De resultaten van de logistische regressie laten echter geen genderverschillen zien. Niet alleen in het model voor het behoeftebeginsel maar ook in de andere modellen is geslacht geen voorspellend persoonskenmerk. Wel levert een multinomiale logistische regressieanalyse op dat vrouwen meer dan mannen de prestatiebeginselen verkiezen boven het gelijkheidsbeginsel $(B=-0,31, p=0,025)$. De conclusie is dat de resultaten niet in lijn zijn met hypothese 3 .

Wanneer we naar leeftijd kijken, dan toont de analyse van de data aan dat dit persoonskenmerk een sterke samenhang vertoont met verdelingsbeginselen. We zien dat ouderen wezenlijk meer het behoeftebeginsel als leidend hanteren dan jongeren. Onder jongeren zijn de andere beginselen juist dominant. We zien dat zij meer dan ouderen het subjectief en/of objectief prestatiebeginsel als leidend hanteren bij de verdeling van geld. Ook geldt dat hoe jonger de respondent, des te meer gekozen wordt voor een gelijke verdeling. De conclusie moet dus zijn dat jongeren en ouderen geld wezenlijk anders verdelen, in lijn met onze verwachtingen in hypothese 4 . 


\section{Conclusie en discussie}

We hebben een empirisch onderzoek uitgevoerd, representatief voor de Nederlandse bevolking van 18 jaar en ouder, naar de opvattingen over een rechtvaardige verdeling van een geldbedrag. Ons doel was om individueel verdelingsgedrag beter te begrijpen en dan met name hoe mensen verschillende verdelingsbeginselen tegen elkaar afwegen en welke persoonskenmerken invloed hebben op hun keuze voor een bepaald beginsel. Voor de beginselen (behoefte, gelijkheid, subjectieve prestatie en objectieve prestatie) hebben we aansluiting gezocht bij de theorie van Aristoteles, uitgewerkt door Mathiesen (1965) en Næss (1969). Behoefte en gelijkheid zijn bekend uit de literatuur. Aanvullend hebben de prestatiebeginselen voor de nodige duidelijkheid gezorgd. De in de literatuur genoemde verdelingscriteria als opleiding (education) en beroep (occupation) lijken ambigu. Zo is een student die met enorme inspanning zijn VMBO-diploma haalt (subjectieve prestatie) moeilijk te vergelijken met een student die door afkomst en/of intellect zonder veel inspanning zijn universitaire graad haalt (objectieve prestatie).

Toetsing van de invloed van persoonskenmerken levert inzichten op over welke groepen in de bevolking een bepaald beginsel als leidend hanteren en welke groepen niet. Wij hebben aanwijzingen gevonden dat gelijk verdelen meer voorkomt onder niet-gelovigen, jongeren en VVDstemmers. Dit blijkt precies omgekeerd te zijn wanneer we kijken naar het behoeftebeginsel. Verdelen naar behoefte domineert onder gelovigen. Blijkbaar speelt geloof in onze maatschappij, waarin zich al decennialang een proces van ontkerkelijking voltrekt, nog steeds een rol van betekenis. Ook bij ouderen domineert het behoeftebeginsel, terwijl dit beginsel juist minder voorkomt onder VVD-stemmers. De prestatiebeginselen, tot slot, zijn leidend onder jongeren en worden door vrouwen verkozen boven het gelijkheidsbeginsel.

We kunnen ook de balans opmaken geredeneerd vanuit de persoonskenmerken. VVD-stemmers verdelen wezenlijk anders dan degenen die niet op VVD stemmen, terwijl PVV- en SP-stemmers zich niet onderscheiden van andere stemmers in hun keuze voor verdelingsbeginselen. Bestudering van geslacht levert geen verschil op tussen mannen en vrouwen in het hanteren van het behoeftebeginsel, maar wel op de prestatiebeginselen. Leeftijd vertoont wel grote samenhang met verdelingsbeginselen. Ouderen kiezen meer dan jongeren voor het behoeftebeginsel, die veeleer een voorkeur hebben voor de prestatiebeginselen. Elders zijn resultaten gerapporteerd die hier haaks op staan (Arts \& Gelissen, 20o1; Linkey \& Alexander, 1998), terwijl relatief recent empirisch materiaal van het Sociaal en Cultureel 
Planbureau (2014) in lijn is met onze bevindingen. Vervolgonderzoek moet uitwijzen of de door ons gevonden samenhang voor Nederland beklijft.

Ondanks de invloed van deze persoonskenmerken op verdelingsbeginselen, laat ons onderzoek met behulp van de multiniveau-analyse een grote mate van contextualiteit van oordelen zien. Belangrijk daarbij is het pluralisme dat wij als theoretisch kader hebben gehanteerd. De empirische resultaten van ons onderzoek zijn in lijn met pluralistische theorieën die stellen dat mensen niet een enkel principe van rechtvaardigheid of een duidelijke prioritering van principes hanteren. Hoewel gelijkheid en vooral behoefte belangrijk blijken voor onze respondenten, hechten zij nog meer gewicht aan het verschil tussen de casus onderling. Noemenswaardig is dat slechts 18,7 procent van de respondenten aan alle vier de behoeftige families evenveel geld geeft en slechts 29,7 procent standvastig is in hun keuze voor het behoeftebeginsel als leidend beginsel. Oftewel, de keuze voor (of tegen) het behoeftebeginsel lijkt allesbehalve evident voor onze respondenten. Eenzelfde conclusie lijkt op zijn plaats, zij het in mindere mate, voor het gelijkheidsbeginsel; van alle respondenten is 55,1 procent standvastig in of zij voor een gelijke dan wel ongelijke verdeling kiezen. Wij bevinden ons met deze bevindingen in goed gezelschap, want de literatuur over verdelende rechtvaardigheid kent empirisch onderzoek dat benadrukt dat eigenschappen van de specifieke situatie een bepaald beginsel meer of minder dominant kunnen maken bij het oordelen over verdelingen (Gatskova, 2013; Scott \& Bornstein, 2009). Dit onderschrijft het belang van het gebruik van verschillende casus, zoals wij gedaan hebben, om op geaggregeerd niveau tot een gefundeerde conclusie te komen. Vervolgonderzoek kan zich richten op een verdere verkenning van contextuele factoren die een rol spelen bij oordeelsvorming over rechtvaardige verdeling. Wij zien dit als een nodige aanvulling op ons onderzoek naar de invloed van persoonskenmerken.

Zelf hebben wij hierover nog aanvullende data tot onze beschikking. Zo merkten wij al eerder op (zie eindnoot 3) dat de opvattingen van respondenten over de verdeling van aandelen vaak een eigen weg volgen. Een andere factor die mogelijk ook een rol speelt, is de waarde van het te verdelen goed of bedrag. We hebben in de paragraaf Data en methoden summier aangegeven dat we ook de mening van de respondenten hebben gevraagd indien zij niet $€ 1000$ maar slechts $€ 100$ te verdelen hebben. Afhankelijk van de betreffende verdeling kiest dan 17 tot 21 procent van de respondenten voor een andere verdeling van het geld. Bij slechts 4 procent van de respondenten is te zien dat ze elke keer dat er $€ 100$ kan worden verdeeld, kiezen voor een andere verdeling. Dat is overigens steeds een verdeling ten 
gunste van de familie die staat voor het behoeftebeginsel. De vraag wordt dan interessant hoe de respondenten zullen verdelen als het niet om $€ 100$ of $€ 1000$ gaat, maar om $€ 10.000$ of $€ 100.000$. Zouden dan de families die staan voor het objectief of subjectief prestatiebeginsel met meer geld bedacht worden en zo ja, hoeveel meer? Hierbij past de kanttekening dat naar schatting (zie Inleiding) de helft van alle respondenten niet over enig vermogen beschikt en $€$ 10oo voor hen al een groot bedrag is.

Onze toepassing van de multiprinciple justice theory met vier verdelingsbeginselen heeft belangrijke informatie opgeleverd. Respondenten hebben veelvuldig gebruik gemaakt van de mogelijkheid om voor meerdere verdelingsbeginselen tegelijk te kiezen met een weging van de gekozen beginselen. De prestatiebeginselen leveren daarbij de beoogde nuancering op. Weliswaar wegen het behoefte- en het gelijkheidsbeginsel zwaarder, maar de voorkeur van jongeren en vrouwen voor de prestatiebeginselen is evenwel een nieuwe bevinding. Bovendien is opvallend dat mensen een zekere consistentie aan de dag leggen bij de keuze voor de prestatiebeginselen en dan vooral het objectief prestatiebeginsel. Voor de families die in onze casus het objectief prestatiebeginsel vertegenwoordigen, geldt dat áls zij het grootste bedrag krijgen toebedeeld, dit in bijna alle geschetste situaties gebeurt. De resultaten van ons onderzoek dragen bij aan het beter begrijpen van in hoeverre burgers de bestaande verdeling als rechtvaardig beschouwen. En dat is mogelijk van belang voor beleidsmakers bij het nemen van distributieve beslissingen.

\section{Noten}

1 Het Forum voor Democratie laten we buiten beschouwing, omdat de verzameling van onze data uit de enquête is afgerond vóór de verkiezingen van 2017 toen deze partij voor het eerst in het parlement kwam.

2 De dataset behorend bij dit artikel en verdere documentatie is te raadplegen bij Data Archiving and Networked Services (DANS) in Den Haag (digital object identifier: 10.17026/dans-xhu-qqzd)

3 Er is ook een vijfde casus, die in dit onderzoek niet wordt meegenomen, omdat deze betrekking had op de verdeling van aandelen in plaats van een geldbedrag en de antwoorden van respondenten voor deze verdeling wezenlijk bleken af te wijken van die voor de andere verdelingen.

\section{Literatuur}

Aristoteles (1999). Ethica Nicomachea. In C. Pannier \& J. Verhaeghe (red.), Aristoteles, Ethica Nicomachea (pp. 139-173). Groningen: Historische uitgeverij. 
Aristoteles (2005). Ethica Nicomachea. In C. Hupperts \& B. Poortman (red.), Aristoteles, Ethica Nicomachea (pp. 247-295). Budel: Damon.

Arts, W. \& Gelissen, J. (2001). Welfare states, solidarity and justice principles: Does the type really matter? Acta Sociologica, 94, 283-299.

Boom, W.H. van (2019). Norm en normativiteit in het vermogensrecht (preadvies CJV2019). Zutphen: Paris.

Bornstein, B., Gervais, S., Dietrich, H. \& Escamilla J. (2014). All else being equal: Overcoming the egalitarian norm. In B. Bornstein \& R. Wiener (red.), Justice, conflict and wellbeing (pp. 3-30). New York: Springer.

Centraal Bureau voor de Statistiek (2019). Vermogensstatistiek 2019: Vermogen van huishoudens, totaal, top $1 \%$ en top $0,1 \%$ hoogste vermogens $2011-2017$.

Cohn, S., White, S.O. \& Sanders, J. (200o). Distributive and procedural justice in seven nations. Law and Human Behavior, 24, 553-579.

Debusscher, M. \& Elchardus, M. (2002). Het draagvlak van de solidariteit. Deelrapport 4. De steun voor de sociale zekerheid. Brussel: Vrije Universiteit.

Dekker, P. \& Ridder, J. den (2014). Polariseert Nederland? Ontwikkelingen in politiek-culturele tegenstellingen. In C. Vrooman, J. Boelhouwer \& M. Gijsberts (red.), Verschil in Nederland: Sociaal en cultureel rapport 2014 (pp. 103-129). Den Haag: Sociaal en Cultureel Planbureau.

Durkheim, E. (1968). Les règles de la méthode sociologique (1895). Paris: P.U.F.

Eagly, A.H. (1987). Sex differences in social behavior: A social-role interpretation. Hillsdale: Erlbaum.

Eckhoff, T. (1974). Justice: Its determinants in social interaction, Rotterdam: Universitaire Pers Rotterdam (Rettferdighet ved utveksling og fordeling av verdier. Oslo: Universitetsforlaget 1970).

Eckhoff, T. (1966). Justice, efficiency and self-made rules in public administration. In: T. Eckhoff (red.), Rettferdighet og rettssikkerhet: Justice and the rule of law (pp. 66-9o). Oslo: Tanum Verlag.

Gatskova, K. (2013). Distributive justice attitudes in Ukraine: Need, desert or social minimum? Communist and Post-Communist Studies, 46, 227-241.

Gilligan, C. (1982). In a different voice: Psychological theory and women's development. Cambridge/ London: Harvard University Press.

Howell, S.E. \& Day, C.L. (2000). Complexities of the gender gap. The Journal of Politics, 62, 858-874.

Kluegel, J.R. \& Miyano, M. (1995). Justice beliefs and support for the welfare state in advanced capitalism. In J.R. Kluegel, D.S. Mason \& B. Wegener (red.), Social justice and political change. Public opinion in capitalist and post-communist states (pp. 81-105). New York: Aldine de Gruyter.

Lamont, J. \& Favor, C. (2017). Distributive Justice. In E.N. Zalta (red), Stanford Encyclopedia of Philosophy (pp. 1-24), https://plato.stanford.edu/archives/win2017/entries/justice-distributive/https://plato.stanford.edu/archives/win2o17/entries/justice-distributive/

Linkey, H.E. \& Alexander, S. (1998). Need norm, democratic influence, social role, and justice judgment. Current Psychology, 17, 152-162.

Lucardie, P. \& Voerman, G. (2012). Populisten in de polder. Amsterdam: Boom.

Mathiesen, T. (1965). The defences of the weak: A sociological Study of a Norwegian correctional institution. London: Tavistock.

Miller, D. (1999). Social justice. Cambridge, MA: Harvard University Press.

Næss, S. (1969). Rettferdighets-holdninger: En undersøkelse av skolebarn og laerere. Oslo: Institutt for Rettsociologi og Forvaltningslaere.

Næss, S. (z.j.). Schoolchildren's ideas of justice (artikel). Oslo: Institutt for Rettsociologi og Forvaltningslaere. 
Oorschot, W.J.H. van (200o). De legitimiteit van sociale zekerheid. Een sociologische analyse van motieven voor solidariteit. In S. Klosse (red.), Sociale zekerheid: Een ander gezichtspunt. Toekomstperspectief vanuit vier disciplines (pp. 37-76). Brugge: Die Keure.

Piaget, J. (1932). Le jugement moral chez l'enfant. Paris: P.U.F.

Piketty, T. (2019). Capital et idéologie. Paris: Seuil.

Piketty, T. (2014). Kapitaal in de 21ste eeuw. Amsterdam: De Bezige Bij.

PVV (2012). Verkiezingsprogramma 2012.

Rawls, J. (1972). A theory of justice. Oxford: Oxford University Press.

Reybrouck, D. van (2011). Pleidooi voor populisme. Amsterdam: De Bezige Bij.

Roosma, F. (2019). Wie verdient nog onze solidariteit? Veranderingen in solidariteitsgevoelens met ouderen, zieken en gehandicapten, werklozen en immigranten in de 21ste eeuw. Mens en Maatschappij, 94, 483-505.

Scott, J.T. \& Bornstein, B.H. (2009). What's fair in foul weather and fair? Distributive justice across different allocation contexts and goods. The Journal of Politics, 71, 831-846.

SP (2013-2017). Verkiezingsprogramma 2013-2017.

Tabata, L.N., Thomas, S.L. \& Heck, R.H. (2012). Multilevel modeling of categorical outcomes using IBM SPSS. New York: Routledge.

Velde, H. te (2010). Van regentenmentaliteit tot populisme: Politieke tradities in Nederland. Amsterdam: Bert Bakker.

VVD (2012-2017). Verkiezingsprogramma 2012-2017.

Vermeij, L., Sonck, N. \& Broek, A. van den (2014). Jong versus oud? In C. Vrooman, J. Boelhouwer \& M. Gijsberts (red.), Verschil in Nederland: Sociaal en cultureel rapport 2014 (pp. 227-250). Den Haag: Sociaal en Cultureel Planbureau.

Wilterdink, N. (2015). Vermogensongelijkheid in Nederland. Amsterdam: Van Gennep.

\section{Over de auteurs}

EvERT-JAN Rotshuizen is buitenpromovendus aan de Faculteit der Rechtsgeleerdheid van de Universiteit Leiden.

E-mail: e.j.rotshuizen@umail.leidenuniv.nl

Helen PluUt is universitair hoofddocent aan de Faculteit der Rechtsgeleerdheid van de Universiteit Leiden. Haar onderzoek richt zich op arbeidspsychologische vraagstukken.

E-mail: h.pluut@law.leidenuniv.nl

Willem VAN Boom is hoogleraar civiel recht aan de Faculteit der Rechtsgeleerdheid van de Universiteit Leiden.

E-mail: w.h.van.boom@law.leidenuniv.nl 


\section{Appendix}

\section{De vijf casus}

\section{Casus 1}

Mevrouw Mol heeft vier kinderen, ze werkt niet. Haar man heeft een kantoorbaan en neemt vaak werk mee naar huis. [behoefte]

Meneer Stam heeft een bakkerswinkel. Hij staat de hele dag in de bakkerij en zijn vrouw helpt de klanten. Ze hebben twee kinderen. [subjectieve prestatie]

Mevrouw Bleeker heeft vier kinderen, ze werkt parttime (15 uur). Haar man is eigenaar van drie goed lopende bloemenzaken, die hij tien jaar geleden van zijn vader heeft overgenomen. [objectieve prestatie]

\section{Casus 2}

Mevrouw Klein heeft drie jaar geleden haar man verloren. Ze heeft drie kinderen waarvan er één nog niet naar school gaat. Ze heeft een beperkt weduwenpensioen. [behoefte]

Meneer Van Beek is getrouwd en heeft twee kinderen. Hij is directeur van een reclamebureau. Hij ontvangt zakenrelaties meestal thuis. [objectieve prestatie]

Meneer De Vries is getrouwd en heeft twee jonge kinderen. Hij heeft een kleine maar drukke buurtwinkel. [subjectieve prestatie]

Casus 3 betreft de verdeling van aandelen die in het artikel niet wordt behandeld.

Een bedrijf bestaat honderd jaar en de directie wil bij deze gelegenheid ook iets voor het personeel doen. Besloten wordt om ieder personeelslid dat langer dan drie jaar bij het bedrijf in dienst is, aandelen te geven. Al jarenlang leveren die aandelen geld op (dividend).

We nemen drie mensen die in verschillende functies werken:

Meneer De Jager heeft bijna 20 jaar als magazijnbediende bij dit bedrijf gewerkt en zal over niet al te lange tijd met pensioen gaan. De uitkeringen op de aandelen zouden voor hem een mooi spaarpotje zijn. Als hij met pensioen gaat, kan hij daarmee zijn AOW aanvullen. [behoefte]

Meneer Berkel werkt ook al heel lang bij het bedrijf. Door verschillende avondcursussen te volgen is hij ten slotte chef van de bestelafdeling geworden. Hij zit in een pensioenfonds, zodat hij straks niet alleen van 
zijn AOW behoeft rond te komen. [subjectieve prestatie]

Meneer Jansen is ingenieur. Hij is vijf jaar geleden afgestudeerd en meteen bij dit bedrijf gekomen. Hij is hoofd van de onderzoeksafdeling en doet ook zelf veel onderzoek. Hij is vaak tot's avonds laat in het laboratorium. [objectieve prestatie]

U hebt de beschikking over 6 o aandelen die allemaal evenveel waard zijn. U mag die verdelen. Hoeveel aandelen geeft $u$ aan de genoemde personen?

\section{Casus 4}

Meneer Brand heeft vroeger hard gestudeerd en heeft nu een hoge positie bij een groot bedrijf. [objectieve prestatie]

Meneer Van Veen heeft na de basisschool korte tijd een technische opleiding gevolgd, maar die niet afgemaakt. Hij is toen voor een baas gaan werken en heeft daar het vak geleerd. Hij verdient nu goed zijn brood. [subjectieve prestatie]

Mevrouw Koper leeft van haar AOW. Ze is slecht ter been en komt weinig meer op straat. [behoefte]

\section{Casus 5}

Meneer Van Zanen is onderdirecteur van een fabriek. Hij woont in een van de buitenwijken van de stad. Hij is getrouwd en heeft vier jonge kinderen. [objectieve prestatie]

Meneer Van Pelt is metaalarbeider. De fabriek waar hij werkt is over de kop gegaan en hij werkt nu in een fabriek in een andere stad. De verbinding met het openbaar vervoer tussen de beide steden is slecht. Als gevolg daarvan is hij veel tijd kwijt met reizen. Hij is getrouwd en heeft drie jonge kinderen. [behoefte]

Meneer Kruiters is ook metaalarbeider en werkt op dezelfde fabriek als meneer Van Pelt. Hij woont in de stad waar de fabriek staat. Hij gaat meestal op de fiets naar zijn werk. 's Avonds knapt hij regelmatig dingen bij andere mensen op. Daarvoor heeft hij een auto nodig. Hij verdient zo een aardig centje bij. Hij is getrouwd en heeft twee jonge kinderen. [subjectieve prestatie] 